\title{
Comparison of Proteomics Profiles Between Xenografts Derived from Cell Lines and Primary Tumors of Thyroid Carcinoma
}

\author{
Luo Fang2*, Yu-jia Liu ${ }^{3 *}$, Yi-wen Zhang3,4, Zong-fu Pan3,4, Li-ke Zhong2, Lie-hao Jiang1,4, Jia-feng Wang1,4, \\ Xiao-wei Zheng 3 , Ling-ya Chen², Ping Huang ${ }^{3,4}$, Ming-hua Ge ${ }^{1,4}$, Zhuo Tan ${ }^{1,4}{ }^{\bowtie}$
}

1. Department of Head and neck \& thyroid surgery, Zhejiang Provincial People's Hospital; People's Hospital of Hangzhou Medical College, 310010, Hangzhou, Zhejiang, China.

2. Department of Pharmacy, The Cancer Hospital of the University of Chinese Academy of Sciences (Zhejiang Cancer Hospital), Institute of Basic Medicine and Cancer (IBMC), Chinese Academy of Sciences, 1\# Bashan East Road, 310022, Hangzhou, China.

3. Department of Pharmacy, Zhejiang Provincial People's Hospital; People's Hospital of Hangzhou Medical College, 310010, Hangzhou, Zhejiang, China.

4. Key Laboratory of Endocrine Gland Diseases of Zhejiang Province, 310010, Hangzhou, Zhejiang, China.

* Luo Fang and Yujia Liu contributed equally to this work.

$\triangle$ Corresponding author: Zhuo Tan, Department of Head and neck \& thyroid surgery, Zhejiang Provincial People's Hospital, 158\# Shangtang Road, Hangzhou, Zhejiang province, 310010, China. Tel: +86-0571-88128108; E-mail: tanzhuo@zjcc.org.cn

(0) The author(s). This is an open access article distributed under the terms of the Creative Commons Attribution License (https://creativecommons.org/licenses/by/4.0/). See http://ivyspring.com/terms for full terms and conditions.

Received: 2020.07.20; Accepted: 2020.12.26; Published: 2021.01.31

\begin{abstract}
Patient-consistent xenograft model is a challenge for all cancers but particularly for thyroid cancer, which shows some of the greatest genetic divergence between human tumors and cell lines. In this study, proteomic profiles of tumor tissues from patients, included anaplastic thyroid carcinoma (ATC) and papillary thyroid carcinoma, and xenografts (8305C, 8505C, FRO, BAPAP and IHH4) were obtained using HPLC-tandem mass spectrometry and compared based on all proteins detected $(3,961)$, cancer-related proteins and druggable proteins using pairwise Pearson's correlation analysis. The human tissue showed low proteomic similarity to the ATC cell lines (8305C, $r=0.344-0.416$; 8505C, 0.47-0.579; FRO, 0.267-0.307) and to PTC cell lines (BCPAP, 0.303-0.468; IHH4, 0.262-0.509). Human tissue showed the following similarity to cell lines at the level of 135 cancer-related pathways. The ATC cell lines contained 47.4\% of the cancer-related pathways (19.26\%-33.33\%), while the PTC cell lines contained 40\% (BCPAP, $25.93 \%$; IHH4, $28.89 \%$ ). In patient tumor tissues, $44-60$ of 76 and 52-53 of 93 druggable proteins were identified in ATC and PTC tumors, respectively. Ten and 29 druggable proteins were not identified in any of the ATC and PTC xenografts, respectively. We provide a reference for CDX selecting in in vivo studies of thyroid cancer.
\end{abstract}

Key words: Proteomics, Cell-line Derived Xenografts, Primary Tumor, Thyroid Cancer.

\section{Introduction}

The most commonly used preclinical in vivo model of cancer is a cell line-derived xenograft (CDX), which is generated by transplanting human tumor cells into immunocompromised mice. While CDX studies have generated valuable insights, CDX tissue and tumor patients differ in their behavior, making CDX inadequate for understanding and predicting human tumor behavior and response to therapy [1]. CDX tissue differs genetically from patient tissue because CDX tissue is derived from a single patient, who differs genetically from other patients with the same cancer, and because cell lines is vulnerable to selected evolution [2,3] and genomic instability [4]. CDX and original human tumor tissue differ not only in their intrinsic genetics from cell line but also in their mechanisms of growth. For example, a proteomic study found that six of 10 pathways differed substantially between high-grade glioma cell lines and their CDX's [5]. 
Table 1. Clinical and pathological characteristics of patients who donated primary tumor tissue

\begin{tabular}{|c|c|c|c|c|}
\hline Patient NO. & Histology & Sex & Age (years) & Tumor size $(\mathrm{cm})$ \\
\hline 1 & ATC & $\mathrm{M}$ & 75 & 5.2 \\
\hline 2 & ATC & M & 54 & 6.0 \\
\hline 3 & ATC & M & 47 & 2.5 \\
\hline 4 & ATC & $\mathrm{F}$ & 72 & 7.0 \\
\hline 5 & ATC & $\mathrm{M}$ & 77 & 10.0 \\
\hline 6 & PTC & M & 65 & 1.0 \\
\hline 7 & PTC & $\mathrm{F}$ & 68 & 2.0 \\
\hline 8 & PTC & $\mathrm{M}$ & 58 & 1.6 \\
\hline 9 & PTC & $\mathrm{M}$ & 54 & 1.4 \\
\hline 10 & PTC & $\mathrm{M}$ & 54 & 1.5 \\
\hline 11 & PTC & $\mathrm{F}$ & 67 & 0.6 \\
\hline 12 & PTC & $\mathrm{F}$ & 43 & 4.5 \\
\hline 13 & PTC & M & 42 & 2.4 \\
\hline 14 & PTC & $\mathrm{M}$ & 58 & 4.0 \\
\hline 15 & PTC & $\mathrm{F}$ & 58 & 5.0 \\
\hline 16 & PTC & M & 58 & 2.3 \\
\hline 17 & PTC & $\mathrm{F}$ & 59 & 2.5 \\
\hline 18 & PTC & $\mathrm{F}$ & 22 & 2.5 \\
\hline 19 & PTC & M & 66 & 3.0 \\
\hline 20 & PTC & $\mathrm{F}$ & 21 & 2.3 \\
\hline 21 & PTC & $\mathrm{F}$ & 25 & 4.5 \\
\hline 22 & PTC & $\mathrm{F}$ & 47 & 1.2 \\
\hline 23 & PTC & $\mathrm{F}$ & 28 & 2.5 \\
\hline 24 & PTC & $\mathrm{M}$ & 52 & 3.5 \\
\hline 25 & PTC & $\mathrm{F}$ & 45 & 0.6 \\
\hline 26 & PTC & $\mathrm{F}$ & 62 & 2.0 \\
\hline 27 & PTC & $\mathrm{F}$ & 56 & 1.7 \\
\hline 28 & PTC & $\mathrm{F}$ & 50 & 0.9 \\
\hline 29 & PTC & $\mathrm{F}$ & 54 & 0.9 \\
\hline 30 & PTC & $\mathrm{M}$ & 48 & 0.6 \\
\hline 31 & PTC & $\mathrm{M}$ & 48 & 0.8 \\
\hline 32 & PTC & $\mathrm{M}$ & 55 & 1.0 \\
\hline 33 & PTC & M & 53 & 0.8 \\
\hline
\end{tabular}

Selecting appropriate cell lines is essential for accurate cancer studies, but choosing the best cells is often purely empirical. Common cell lines are often used, but their genetic consistency with tumor samples is often unclear. Ovarian cancer, for example, may be better studied using some rarely used cell lines than commonly used lines [6]. Systematic analysis of the similarities and differences between CDX's and human tumors may help guide the selection of appropriate CDX's to mimic tumors for basic cancer research and translational studies.

Towards this goal, various cancer cell lines have been evaluated, as have pooled analysis of various cancers [1, 6-12] or specific types of solid tumors, including breast cancer, hepatocellular carcinoma, and melanoma [13-15]. Moderate correlation was observed between mRNA levels in cell lines and primary solid tumors, with a median correlation coefficient of 0.6 [12]. But, the lowest corresponding coefficient (only 0.29) was found in thyroid cancer and $<0.3$ for the two subtypes of thyroid cancer, papillary thyroid carcinoma (PTC) and anaplastic thyroid carcinoma (ATC) [16]. PTC is more common and involves well-differentiated tumors and good prognosis, while ATC is less common and involves less differentiated, more aggressive tumors. Therefore, the proteomic consistence was also need to be clear.

To provide a rational basis for selecting the most appropriate CDX for thyroid cancer studies, we performed proteomics profiling of ATC and PTC tumors as well as several CDX's (ATC: 8505C, 8305C, FRO; PTC: BCPAP, IHH4). The two types of cancer tissue were compared in terms of total proteins, cancer-related pathways and druggable proteins. The results lead us to recommend certain cell lines over others for in vivo studies of thyroid cancer.

\section{Materials and Methods}

\section{Primary tumor tissues}

Fresh frozen samples of primary tumor were obtained from five ATC patients (4 men, 1 woman) and 28 PTC patients (13 men, 15 women) who underwent surgery in Zhejiang Cancer Hospital in Hangzhou, China (Table 1). All specimens were flash-frozen after tissue type had been confirmed. This study was approved by the Ethics Committee of Zhejiang Cancer Hospital and performed according to the Declaration of Helsinki and Good Clinical Practice guidelines. Patients provided written informed consent for their tissue to be used in this study.

\section{Cell lines and xenografts}

Five thyroid carcinoma cell lines were used in this study: the ATC cell lines 8305C, 8505C, and FRO were obtained from the Shanghai Cell Bank of the Chinese Academy of Sciences (Shanghai, China); while the PTC cell lines BCPAP and IHH4 were obtained from professor Haixia Guan (Department of Endocrinology and Metabolism, The First Affiliated Hospital of China Medical University, Shenyang, P.R. China). Cell lines 8305C and 8505C were cultured in DMEM, while the other lines were cultured in RPMI-1640. In all cases, the medium was supplemented with streptomycin $(100 \mathrm{U} / \mathrm{mL})$ and penicillin $(100 \mathrm{U} / \mathrm{mL})$ as well as fetal bovine serum (FBS) to a final concentration of 5\% (FRO) or 10\% (all other lines). Cultures were incubated at $37{ }^{\circ} \mathrm{C}$ in a humidified atmosphere of $5 \% \mathrm{CO}_{2}$.

Female BALB/c nude mice weighing 16-22 g [Animal License No. SCXK-(Shanghai)2015000521727] were obtained from the Shanghai Laboratory Animal Center (Shanghai, China) and housed at the Center for Drug Safety Evaluation at Zhejiang University [Hangzhou, China; Animal License No. SYXK (Zhejiang) 2012-0178]. Cultured cell lines were subcutaneously injected into the right flank. Once tumor volumes reached about $100 \mathrm{~mm}^{3}$, animals were sacrificed and tumor tissues were 
harvested and homogenized. Animal studies were conducted according to the National Research Council's guidelines and approved by the Committee on the Ethics of Animal Experiments of Zhejiang Cancer Hospital and the Center for Drug Safety Evaluation at Zhejiang University.

\section{Proteomic analysis}

Total proteins from tumor tissues $(25 \mathrm{mg})$ were extracted and digested with trypsin according to the Filter-Aided Sample Preparation method. The digest was desalted and analyzed on a liquid chromatography-mass spectrometry system consisting of a Nano-nLC 1000 system (Thermo Fisher Scientific) connected to a linear quadrupole ion trap-Orbitrap (LTQ Orbitrap Elite) mass spectrometer (Thermo Fisher Scientific), which was equipped with a Proxeon NanoSpray Flex Ion Source (Thermo Fisher Scientific). Peptides were eluted on an Acclaim PepMap RSLC column $(15 \mathrm{~cm}, 50 \mu \mathrm{m}, 2 \mu \mathrm{m})$ using a 150 min-last gradient elution program involving acetonitrile and $0.1 \%(\mathrm{v} / \mathrm{v})$ formic acid at a flow rate of $250 \mathrm{~nL} / \mathrm{min}$. Optimized mass spectrometry conditions were as follows: full scan mass analysis; $\mathrm{m} / \mathrm{z}$ range, 300-2,000; resolving power, 60,000 (at $\mathrm{m} / \mathrm{z}$ 400, FWHM, 1-second acquisition); ion spray voltage, $1.8 \mathrm{kV}$; ion source temperature, $300{ }^{\circ} \mathrm{C}$; and collision energy, $35 \mathrm{eV}$. Tandem mass spectrometry was performed with rolling collision energy for the top 20 most intense precursor ions with charge states of at least 2+. Mass and composition of precursor and fragment ions were analyzed using Thermo Xcalibur 3.0 software (Thermo Fisher Scientific).

\section{Protein identification and quantification}

Raw spectral data were processed and quantitative ratios determined using PEAKS Studio 8 (Bioinformatics Solutions); parent mass tolerance was $15.0 \mathrm{ppm}$ and fragment mass tolerance was $0.8 \mathrm{Da}$. Results were compared against UNIPROT databases of Piriformospora and Brassica (updated to April 2017). Protein identifications were accepted if the false detection rate (FDR) was $<1 \%$ and if the score $-10 \times \log _{10} \mathrm{P}$ was $>20$. The minimum number of unique peptides was set to 1 , and the maximum number of post-translational modifications was set to 3 . ANOVA was used to assess differences for statistical significance.

\section{Determination of cancer-related pathways and druggable proteins}

Cancer-related genes were determined by mining abstracts indexed in MEDLINE up to 18 September 2017 using the text-mining engine DiGseE [17]. Critical pathways closely related to cancer were identified using DAVID Bioinformatics Resources 6.8.
Statistical significance and significant enrichment were defined as $p<0.10$. The list of 672 human proteins directly related to the mechanisms of action of drugs approved by the US Food and Drug Administration was obtained from Drugbank (Table S1).

\section{Similarity evaluation of primary and xenograft tumors}

Human primary PTC or ATC tumors were compared with the corresponding CDX models in terms of their proteomic profiles or cancer-related pathways. This comparison was performed based on the pairwise Pearson correlation coefficient as described [12], here applied to the normalized expression levels of total detected proteins or proteins enriched in the particular cancer-related pathway under consideration. Similarity at the proteomics level was calculated between each patient and each CDX, while similarity at the level of individual cancer-related pathways was calculated between all ATC or PTC patients and each CDX. In brief, a linear model from the Linear Models for Microarray Data (LIMMA) package was fitted, and the average fold-difference for each protein between primary and xenograft tumors was calculated. Then, the pairwise Pearson's correlation coefficient between tumors and cell lines was calculated based on the fold-differences for all proteins or only for the proteins involved in a certain pathway. Similarity of cancer-related pathways between tumors and CDX's were assessed using the Mann-Whitney U test.

\section{Stratification of cell lines based on desirability for studies of cancer-related pathways}

The cell lines were stratified into three classes based on their desirability as in vivo models for specific pathway research, as measured by the r-value: (1) not recommended, referring to cell lines showing only weak similarity $(r<0.25)$ for specific pathways; (2) recommended, referring to cell lines showing strong similarity $(r>0.60)$, or in the event that all cell lines fail to reach 0.60 , the cell line with the highest r-value; (3) priority recommended, referring to the cell line with the highest r-value that is also $>0.60$.

\section{Results}

A total of 3,961 proteins were identified from tumor samples.

\section{Proteomics-based similarity between primary and xenograft tumors}

After searching 16,167 publications, 4,149 cancer-related genes were identified, of which 2,350 
genes were reported by at least two publications. Based on these 2,350 genes, 135 cancer-related pathways were identified (Table S2). The CDX's in this study showed weak correlations with primary tumors based on total of detectable proteins (Figure 1A): median correlation coefficients were 0.396 (range, $0.344-0.416$ ) for $8305 \mathrm{C}, 0.278$ (range, 0.267-0.307) for FRO, 0.366 (range, 0.303-0.468) for BCPAP, 0.397 (range, 0.262-0.509) for IHH4, and slightly higher for $8505 \mathrm{C}$ at 0.545 (range, $0.470-0.579$ ).

Correlations were also weak based on proteins in cancer-related pathways (Figure 1B). Median correlation coefficients for 135 pathways were 0.43 (range, -0.16-1.00) in the case of ATC and 0.450 (range, $-0.50-0.86)$ in the case of PTC. The $8505 \mathrm{C}$ cell line seemed more similar to ATC patient tissue $(\mathrm{r}=$ $-0.11-1.00$ and 0.36 for quartile $1,0.51$ for quartile 2, and 0.64 for quartile 3$)$ than $8305 \mathrm{C}(\mathrm{r}=-0.26-1.00,0.26$ for quartile 1, 0.39 for quartile 2, 0.56 for quartile $3, p<$ $0.0001)$ or FRO ( $\mathrm{r}=-0.16-1.00,0.32$ for quartile $1,0.43$ for quartile 2, 0.55 for quartile $3, p=0.0017)$. BCPAP (r $=-0.89-0.91,0.39$ for quartile $1,0.50$ for quartile 2, 0.61 for quartile 3) seemed slightly more similar to PTC patient tissue than IHH4 ( $\mathrm{r}=-1.0-1.0,0.30$ for quartile 1, 0.49 for quartile 2, 0.61 for quartile $3, p=0.0607$ ).

Fewer than one of every three pathways showed strong similarity $(>0.60)$ between primary tumors and CDX's; the proportion was $19.26 \%$ for $8305 \mathrm{C}, 33.33 \%$ for $8505 \mathrm{C}, 22.96 \%$ for $\mathrm{FRO}, 25.93 \%$ for BCPAP, and $28.89 \%$ for IHH4. The two PTC cell lines recapitulated 54 cancer-related pathways $(40.0 \%)$ with high consistency; the three ATC cell lines, 64 (47.4\%). In contrast, the proportion of cancer-related pathways in xenograft tumors showing low consistency $(<0.25)$ with primary tumors was $18.52 \%$ in $8305 \mathrm{C}, 31.11 \%$ in $8505 \mathrm{C}, 22.22 \%$ in $\mathrm{FRO}, 12.59 \%$ in BCPAP, and $27.41 \%$ in IHH4 (Figure 1C-D).

In the case of ATC, many key cancer pathways showed poor consistency between primary tumors and at least one CDX (Figure 2). These pathways included those involving the RIL receptor, FoxO, VEGF, ErbB, Notch, Jak-STAT, TGF-beta, p53, Wnt, Hedgehog, and Toll-like receptor; as well as those regulating pluripotency of stem cells, apoptosis, focal adhesion, cell adhesion, thyroid disease, or ubiquitin-mediated proteolysis. Similarly, many key pathways in PTC showed poor consistency between primary tumors and at least one CDX. These pathways included those involving p53, microRNAs, thyroid hormone and Hedgehog; as well as those regulating pluripotency of stem cells, mismatch repair, base excision repair, nucleotide excision repair, glutathione metabolism, small cell lung cancer; and many immunological pathways involving Fc epsilon
RI, hepatitis $C$, complement and coagulation cascades, NF-kappa B, TNF, and autoimmune responses. In addition, many pathways showing poor consistency between primary and xenograft tumors are known to be important in bladder cancer, melanoma, glioma, non-small cell lung cancer, small cell lung cancer, colorectal cancer, and basal cell carcinoma (Table 2,4).

Cell lines 8305C, 8505C, and FRO emerged as better models for studying 37, 79, or 61 pathways, respectively. These pathways included ones showing low and high consistency between primary and xenograft tumors, and they included several pathways that showed greater similarity in one cell line than in the other two: 11 in cell line 8305C, 34 in 8505C, and 32 in FRO (Table 3). Cell lines BCPAP and IHH4 emerged as better models for studying 89 and 67 pathways, although approximately half of them (54 in BCPAP, 67 in IHH4) did not show high consistency between primary and xenograft tumors (Table 3,5). The spectrum of consistency is shown in Figure 2 and Figure 3.
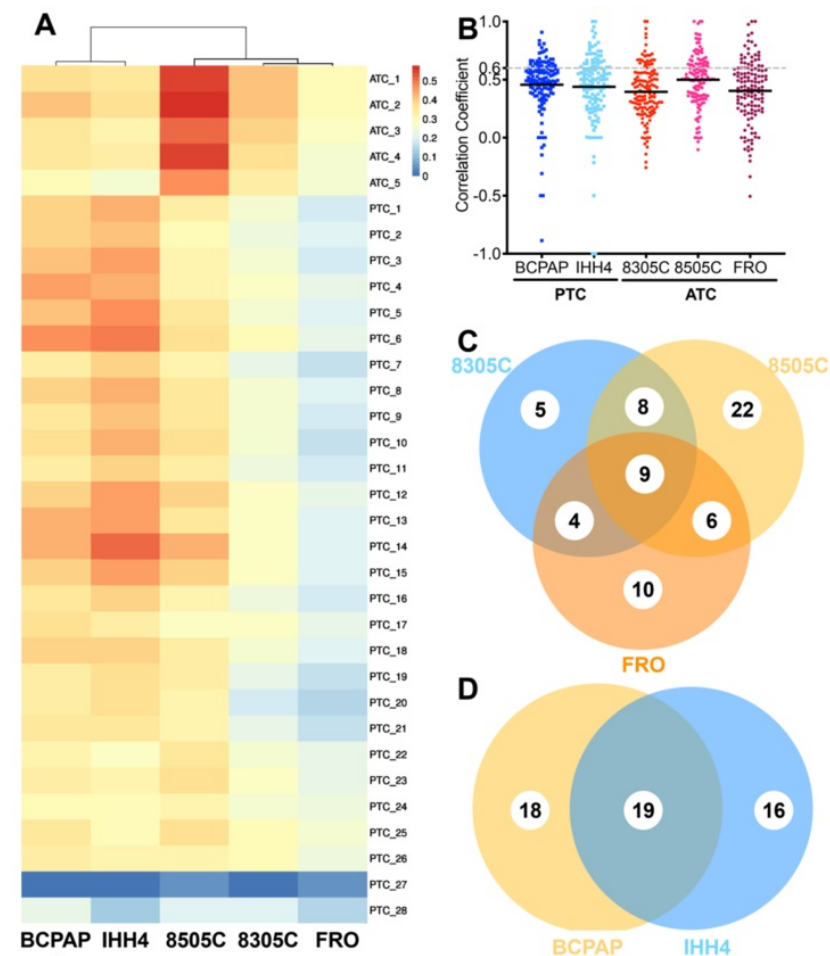

Figure 1. Correlation of individual cancer-related pathways between cell line-derived xenografts and primary tumors of anaplastic thyroid carcinoma (ATC) or papillary thyroid carcinoma (PTC). A. Comparison of proteomic profiles between four cell line-derived xenografts (columns) and primary tumors (rows). Heat map coloring is used to indicate the Pearson correlation coefficient. B. Scatter plot of correlation coefficients for individual cancer-related pathways between cell line-derived xenografts and primary tumors. C-D, Venn diagrams showing overlap of highly consistent pathways between primary and xenograft tumors in (C) PTC and (D) ATC. 


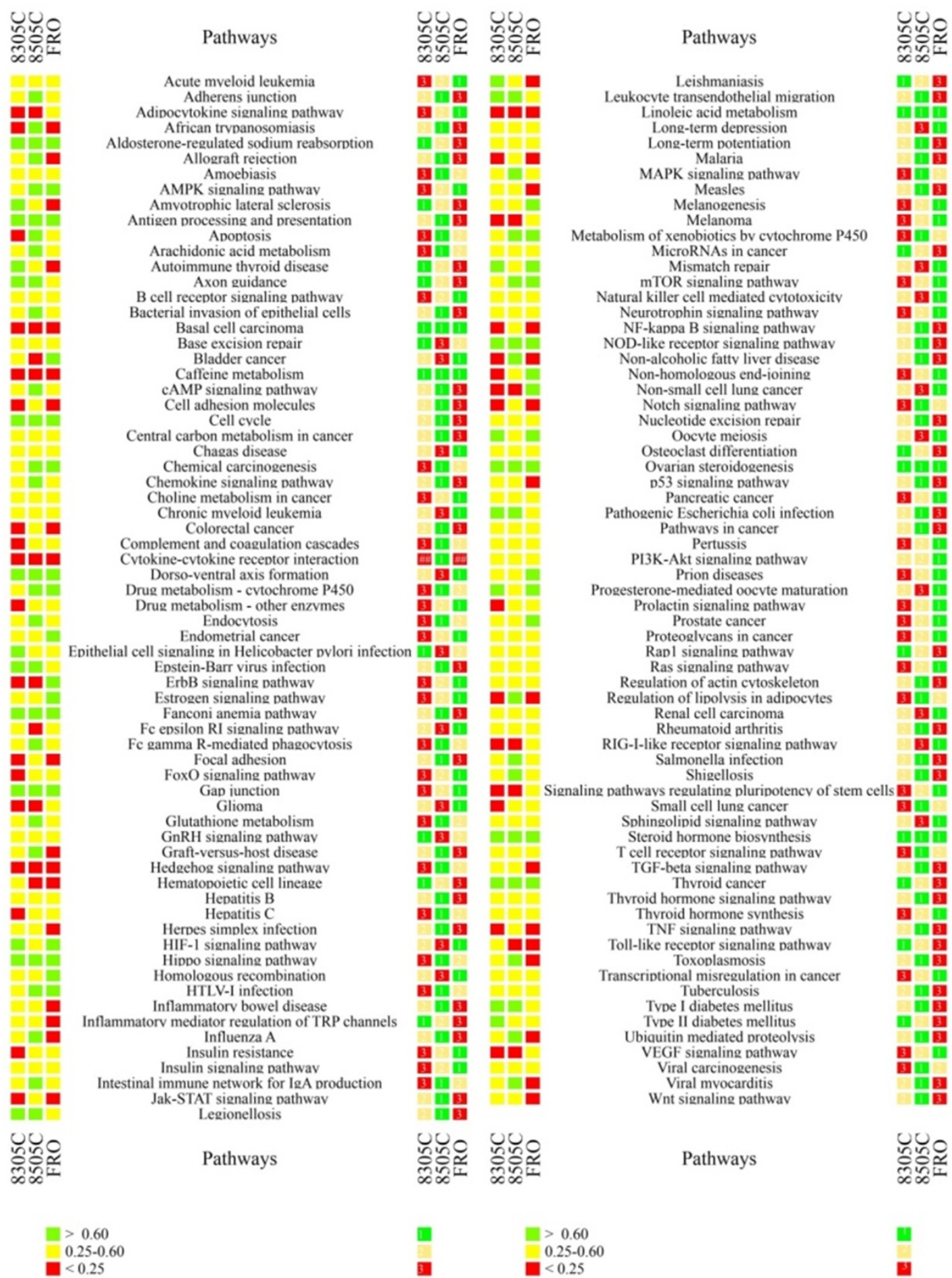

Figure 2. Ranking of individual cancer-related pathways based on correlation coefficients between primary and xenograft ATC tumors. The colored cubes on the left indicate the correlation coefficient as $>0.60$ (green), $0.25-0.60$ (gray), or $<0.25$ (red). The colored cubes on the right indicate the consistency as high (green), moderate (yellow) or low (red).

\section{Druggable proteins}

Of 672 druggable proteins, 76 were identified in primary ATC tumors and 93 in PTC tumors. Among the three ATC CDX's, 31 proteins were detected in all three, while 10 were not detected in any. A total of 60 proteins were identified in $8505 \mathrm{C}, 48$ in FRO, and 44 in
8305C. Of the 93 druggable proteins detected in primary PTC tumors, 12 were also detected in IHH4, 11 in BCPAP, and 41 in both cell lines. A total of 29 proteins were not detected in either cell line (Figure $4)$. 


\section{Discussion/Conclusion}

The phenotypic discrepancies between preclinical models and patients is a challenge in basic cancer studies and in efforts to discover and develop antineoplastic agents [18-21]. This has motivated searches for xenograft tumor models that show maximum similarity to primary human tumors. These efforts are limited by lack of understanding about molecular details of cancer cells [22], and they have been less successful with thyroid cancer. Therefore we employed proteomics and other analyses to compare total protein profiles as well as proteins involved in specific cancer-related pathways between primary thyroid cancer tumors and xenograft tumors derived from several cell lines. Proteomic profiles of 28 primary human PTC tumors and five ATC tumors were compared with proteomic profiles from two PTC CDX's (BCPAP, IHH4) and three ATC CDX's (8305C, 8505C, FRO). Similarity between the two kinds of tumor tissue was assessed according to total proteins, cancer-related proteins, and druggable proteins.

Table 2. Cancer-related pathways grouped based on their similarity between primary and xenograft ATC tumors

\begin{tabular}{|c|c|c|c|c|c|c|c|}
\hline & \multicolumn{7}{|l|}{ Correlation coefficient } \\
\hline & \multicolumn{3}{|l|}{$>0.6$} & \multirow{2}{*}{$\begin{array}{l}0.25-0.6(n=35) \\
\text { Any cell lines }\end{array}$} & \multicolumn{3}{|l|}{$<0.25$} \\
\hline & $8505 \mathrm{C}$ & $8305 \mathrm{C}$ & FRO & & $8505 \mathrm{C}$ & $8305 \mathrm{C}$ & FRO \\
\hline $8505 C$ & $\begin{array}{l}\text { Non-alcoholic fatty liver disease, } \\
\text { cAMP, Toxoplasmosis, MAPK, FC } \\
\text { gamma R-mediated phagocytosis, } \\
\text { Glutathione metabolism, Intestinal } \\
\text { immune network for IgA } \\
\text { production, Endocytosis, } \\
\text { Chemokine, Influenza A, Viral } \\
\text { myocarditis, Allograft rejection, } \\
\text { Graft-versus-host disease, } \\
\text { Adherens junction, Regulation of } \\
\text { lipolysis in adipocytes, Shigellosis, } \\
\text { Bacterial invasion of epithelial cells, } \\
\text { Arachidonic acid metabolism, } \\
\text { Ubiquitin-mediated proteolysis, } \\
\text { Salmonella infection, African } \\
\text { trypanosomiasis, Apoptosis }\end{array}$ & $\begin{array}{l}\text { Leukocyte } \\
\text { transendotheli } \\
\text { al migration, } \\
\text { Axon } \\
\text { guidance, } \\
\text { Epstein-Barr } \\
\text { virus } \\
\text { infection, } \\
\text { Pathogenic } \\
\text { Escherichia coli } \\
\text { infection, Type } \\
\text { I diabetes } \\
\text { mellitus, } \\
\text { Legionellosis }\end{array}$ & $\begin{array}{l}\text { AMPK, mTOR, } \\
\text { HTLV-I infection, } \\
\text { Metabolism of } \\
\text { xenobiotics by } \\
\text { cytochrome P450, } \\
\text { Chemical } \\
\text { carcinogenesis, } \\
\text { Drug metabolism - } \\
\text { cytochrome P450 }\end{array}$ & $\begin{array}{l}\text { Long-term } \\
\text { depression, } \\
\text { Sphingolipid, } \\
\text { GnRH, Pertussis, } \\
\text { Base excision } \\
\text { repair, Thyroid } \\
\text { hormone synthesis, } \\
\text { Pancreatic cancer, } \\
\text { Acute myeloid } \\
\text { leukemia, Chagas } \\
\text { disease, Chronic } \\
\text { myeloid leukemia, } \\
\text { Insulin, PI3K-Akt, } \\
\text { Natural killer } \\
\text { cell-mediated } \\
\text { cytotoxicity, }\end{array}$ & $\begin{array}{l}\text { Fc epsilon } \\
\text { RI, Bladder } \\
\text { cancer }\end{array}$ & $\begin{array}{l}\text { Melanoma, } \\
\text { Adipocytokin } \\
\text { e, Glioma, } \\
\text { RIG-I-like } \\
\text { receptor, } \\
\text { Signaling } \\
\text { pathways } \\
\text { regulating } \\
\text { pluripotency } \\
\text { of stem cells, } \\
\text { VEGF, } \\
\text { Non-small cell } \\
\text { lung cancer, } \\
\text { ErbB }\end{array}$ & $\begin{array}{l}\text { Toll-like receptor, } \\
\text { Hematopoietic cell lineage }\end{array}$ \\
\hline $8305 C$ & - & $\begin{array}{l}\text { Amyotrophic } \\
\text { lateral } \\
\text { sclerosis, } \\
\text { Epithelial cell } \\
\text { signaling in } \\
\text { Helicobacter } \\
\text { pylori } \\
\text { infection, Type } \\
\text { II diabetes } \\
\text { mellitus, } \\
\text { Autoimmune } \\
\text { thyroid } \\
\text { disease, } \\
\text { Leishmaniasis }\end{array}$ & $\begin{array}{l}\text { HIF-1, } \\
\text { Progesterone-medi } \\
\text { ated oocyte } \\
\text { maturation, } \\
\text { Mismatch repair, } \\
\text { Oocyte meiosis }\end{array}$ & $\begin{array}{l}\text { Amoebiasis, } \\
\text { Choline } \\
\text { metabolism in } \\
\text { cancer, } \\
\text { Proteoglycans in } \\
\text { cancer, } \\
\text { MicroRNAs in } \\
\text { cancer, Renal cell } \\
\text { carcinoma, B cell } \\
\text { receptor, } \\
\text { Long-term } \\
\text { potentiation, } \\
\text { Transcriptional } \\
\text { misregulation in } \\
\text { cancer, Hepatitis B, } \\
\text { Thyroid hormone, } \\
\text { Tuberculosis, Viral } \\
\text { carcinogenesis, }\end{array}$ & - & $\begin{array}{l}\text { FoxO, } \\
\text { Prolactin, } \\
\text { Hepatitis C, } \\
\text { Small cell lung } \\
\text { cancer, Drug } \\
\text { metabolism - } \\
\text { other } \\
\text { enzymes, } \\
\text { Complement } \\
\text { and } \\
\text { coagulation } \\
\text { cascades, } \\
\text { Insulin } \\
\text { resistance, } \\
\text { Non-homolog } \\
\text { ous end } \\
\text { joining, } \\
\text { Apoptosis }\end{array}$ & $\begin{array}{l}\text { Focal adhesion, NF-kappa } \\
\text { B, Notch, Colorectal } \\
\text { cancer, TNF, Jak-STAT, } \\
\text { Malaria, Cell adhesion } \\
\text { molecules, Non-alcoholic } \\
\text { fatty liver disease, } \\
\text { Regulation of lipolysis in } \\
\text { adipocytes, African } \\
\text { trypanosomiasis }\end{array}$ \\
\hline FRO & - & - & $\begin{array}{l}\text { Bladder cancer, } \\
\text { Non-small cell } \\
\text { lung cancer, ErbB, } \\
\text { Melanogenesis, } \\
\text { Non-homologous } \\
\text { end joining, } \\
\text { Homologous } \\
\text { recombination, } \\
\text { Endometrial } \\
\text { cancer, Prion } \\
\text { diseases, Estrogen, } \\
\text { Prostate cancer }\end{array}$ & $\begin{array}{l}\text { Ras, Pathways in } \\
\text { cancer, } \\
\text { Neurotrophin, } \\
\text { Central carbon } \\
\text { metabolism in } \\
\text { cancer, Rap1, } \\
\text { Osteoclast } \\
\text { differentiation, } \\
\text { Nucleotide } \\
\text { excision repair, T } \\
\text { cell receptor, } \\
\text { Regulation of actin } \\
\text { cytoskeleton, } \\
\text { Rheumatoid } \\
\text { arthritis }\end{array}$ & - & - & $\begin{array}{l}\text { TGF-beta, Inflammatory } \\
\text { mediator regulation of } \\
\text { TRP channels, } \\
\text { Inflammatory bowel } \\
\text { disease, Herpes simplex } \\
\text { infection, p53, Wnt, } \\
\text { Measles, Amyotrophic } \\
\text { lateral sclerosis, } \\
\text { Autoimmune thyroid } \\
\text { disease, Leishmaniasis, } \\
\text { Toxoplasmosis, Influenza } \\
\text { A, Viral myocarditis, } \\
\text { Allograft rejection, } \\
\text { Graft-versus-host disease, } \\
\text { Ubiquitin-mediated } \\
\text { proteolysis }\end{array}$ \\
\hline ALL & $\begin{array}{l}\text { Thyroid cancer, Dorso-ventral axis } \mathrm{f} \\
\text { processing and presentation, Hippo, } \\
\text { sodium reabsorption, NOD-like rece } \\
\text { Steroid hormone biosynthesis, Ovar }\end{array}$ & $\begin{array}{l}\text { formation, Gap ji } \\
\text {, Cell cycle, Aldc } \\
\text { eptor, Fanconi ar } \\
\text { rian steroidogene }\end{array}$ & $\begin{array}{l}\text { unction, Antigen } \\
\text { osterone-regulated } \\
\text { nemia pathway, } \\
\text { esis }\end{array}$ & & $\begin{array}{l}\text { Hedgehog, } \\
\text { Linoleic acic }\end{array}$ & $\begin{array}{l}\text { Basal cell carcinor } \\
\text { metabolism }\end{array}$ & ma, Caffeine metabolism, \\
\hline
\end{tabular}


Table 3. ATC-related pathways recommended for cell line-based studies based on consistency with CDX's

\begin{tabular}{|c|c|c|c|c|}
\hline \multirow[t]{2}{*}{ Cell line } & \multicolumn{3}{|l|}{ Top 1 consistency } & \multirow[t]{2}{*}{ Non-top 1} \\
\hline & Low consistency & Moderate consistency & High consistency & \\
\hline $8505 \mathrm{C}$ & $\begin{array}{l}\text { Hedgehog } \\
\text { signaling } \\
\text { pathway, Basal } \\
\text { cell carcinoma, } \\
\text { Caffeine } \\
\text { metabolism, } \\
\text { Linoleic acid } \\
\text { metabolism }\end{array}$ & $\begin{array}{l}\text { Inflammatory bowel disease, NF-kappa B } \\
\text { signaling pathway, Jak-STAT signaling } \\
\text { pathway, Malaria, Small cell lung cancer, } \\
\text { Colorectal cancer, Focal adhesion, Notch } \\
\text { signaling pathway, TGF-beta signaling } \\
\text { pathway, TNF signaling pathway, } \\
\text { Hepatitis C, Measles, p53 signaling } \\
\text { pathfway, Amoebiasis, Herpes simplex } \\
\text { infection, Cell adhesion molecules, } \\
\text { Complement and coagulation cascades, } \\
\text { Thyroid hormone signaling pathway, } \\
\text { Long-term potentiation, Viral } \\
\text { carcinogenesis, Hepatitis B, Tuberculosis, } \\
\text { Wnt signaling pathway, T cell receptor } \\
\text { signaling pathway, Nucleotide excision } \\
\text { repair, Pathways in cancer, Central carbon } \\
\text { metabolism in cancer, Regulation of actin } \\
\text { cytoskeleton, Rheumatoid arthritis }\end{array}$ & $\begin{array}{l}\text { African trypanosomiasis, Regulation of } \\
\text { lipolysis in adipocytes, Non-alcoholic fatty } \\
\text { liver disease, Allograft rejection, } \\
\text { Graft-versus-host disease, Viral myocarditis, } \\
\text { Apoptosis, Intestinal immune network for } \\
\text { IgA production, Toxoplasmosis, } \\
\text { Ubiquitin-mediated proteolysis, Glutathione } \\
\text { metabolism, Influenza A, cAMP signaling } \\
\text { pathway, Endocytosis, Chemokine signaling } \\
\text { pathway, Leukocyte transendothelial } \\
\text { migration, MAPK signaling pathway, Fc } \\
\text { gamma R-mediated phagocytosis, Adherens } \\
\text { junction, HTLV-I infection, Bacterial invasion } \\
\text { of epithelial cells, Shigellosis, Epstein-Barr } \\
\text { virus infection, Arachidonic acid metabolism, } \\
\text { Salmonella infection, Type I diabetes mellitus, } \\
\text { Legionellosis, Pathogenic Escherichia coli } \\
\text { infection, Antigen processing and } \\
\text { presentation, Metabolism of xenobiotics by } \\
\text { cytochrome P450, Cell cycle, Chemical } \\
\text { carcinogenesis, Hippo signaling pathway, } \\
\text { Drug metabolism - cytochrome P450, Fanconi } \\
\text { anemia pathway, NOD-like receptor } \\
\text { signaling pathway, Ovarian steroidogenesis, } \\
\text { Steroid hormone biosynthesis }\end{array}$ & $\begin{array}{l}\text { AMPK signaling pathway, mTOR } \\
\text { signaling pathway, Thyroid cancer, Axon } \\
\text { guidance, Gap junction, } \\
\text { Aldosterone-regulated sodium } \\
\text { reabsorption, Dorso-ventral axis } \\
\text { formation }\end{array}$ \\
\hline $8305 \mathrm{C}$ & $\begin{array}{l}\text { Basal cell } \\
\text { carcinoma, } \\
\text { Caffeine } \\
\text { metabolism, } \\
\text { Linoleic acid } \\
\text { metabolism }\end{array}$ & $\begin{array}{l}\text { Hematopoietic cell lineage, Toll-like } \\
\text { receptor signaling pathway, Inflammatory } \\
\text { mediator regulation of TRP channels, } \\
\text { GnRH signaling pathway, MicroRNAs in } \\
\text { cancer, Base excision repair, Osteoclast } \\
\text { differentiation, Rap1 signaling pathway }\end{array}$ & $\begin{array}{l}\text { Amyotrophic lateral sclerosis, Autoimmune } \\
\text { thyroid disease, Type II diabetes mellitus, } \\
\text { Leishmaniasis, Epithelial cell signaling in } \\
\text { Helicobacter pylori infection, Thyroid cancer, } \\
\text { Axon guidance, Aldosterone-regulated } \\
\text { sodium reabsorption, Ovarian } \\
\text { steroidogenesis, Steroid hormone } \\
\text { biosynthesis }\end{array}$ & $\begin{array}{l}\text { Leukocyte transendothelial migration, } \\
\text { Epstein-Barr virus infection, Mismatch } \\
\text { repair, Type I diabetes mellitus, } \\
\text { Legionellosis, Pathogenic Escherichia coli } \\
\text { infection, HIF-1 signaling pathway, } \\
\text { Oocyte meiosis, Gap junction, Antigen } \\
\text { processing and presentation, } \\
\text { Progesterone-mediated oocyte } \\
\text { maturation, Cell cycle, Hippo signaling } \\
\text { pathway, Fanconi anemia pathway, } \\
\text { Dorso-ventral axis formation, NOD-like } \\
\text { receptor signaling pathway }\end{array}$ \\
\hline FRO & $\begin{array}{l}\text { Basal cell } \\
\text { carcinoma, } \\
\text { Caffeine } \\
\text { metabolism, } \\
\text { Linoleic acid } \\
\text { metabolism }\end{array}$ & $\begin{array}{l}\text { Adipocytokine signaling pathway, } \\
\text { Melanoma, Signaling pathways regulating } \\
\text { pluripotency of stem cells, Fc epsilon RI } \\
\text { signaling pathway, VEGF signaling } \\
\text { pathway, RIG-I-like receptor signaling } \\
\text { pathway, Glioma, FoxO signaling } \\
\text { pathway, Pancreatic cancer, Prolactin } \\
\text { signaling pathway, Pertussis, Drug } \\
\text { metabolism - other enzymes, Sphingolipid } \\
\text { signaling pathway, Proteoglycans in } \\
\text { cancer, Insulin signaling pathway, } \\
\text { Thyroid hormone synthesis, Long-term } \\
\text { depression, PI3K-Akt signaling pathway, } \\
\text { B cell receptor signaling pathway, Acute } \\
\text { myeloid leukemia, Transcriptional } \\
\text { misregulation in cancer, Chronic myeloid } \\
\text { leukemia, Chagas disease, Choline } \\
\text { metabolism in cancer, Insulin resistance, } \\
\text { Natural killer cell mediated cytotoxicity, } \\
\text { Ras signaling pathway, Renal cell } \\
\text { carcinoma, Neurotrophin signaling } \\
\text { pathway }\end{array}$ & $\begin{array}{l}\text { Non-small cell lung cancer, Bladder cancer, } \\
\text { ErbB signaling pathway, Non-homologous } \\
\text { end joining, Melanogenesis, Endometrial } \\
\text { cancer, Prion diseases, AMPK signaling } \\
\text { pathway, mTOR signaling pathway, } \\
\text { Mismatch repair, Estrogen signaling } \\
\text { pathway, Homologous recombination, } \\
\text { Prostate cancer, HIF-1 signaling pathway, } \\
\text { Oocyte meiosis, Gap junction, } \\
\text { Progesterone-mediated oocyte maturation, } \\
\text { Dorso-ventral axis formation, Ovarian } \\
\text { steroidogenesis, Steroid hormone } \\
\text { biosynthesis }\end{array}$ & $\begin{array}{l}\text { HTLV-I infection, Thyroid cancer, } \\
\text { Metabolism of xenobiotics by cytochrome } \\
\text { P450, Cell cycle, Chemical carcinogenesis, } \\
\text { Hippo signaling pathway, Drug } \\
\text { metabolism - cytochrome P450, } \\
\text { Aldosterone-regulated sodium } \\
\text { reabsorption, NOD-like receptor } \\
\text { signaling pathway }\end{array}$ \\
\hline
\end{tabular}

CDX's were not very similar to ATC primary tumors when the complete proteomic profiles were considered: the correlation coefficient was 0.39 for 8305C, 0.53 for 8505C, and 0.29 for FRO. Similar results were observed for PTC tumors, where the correlation coefficient was 0.35 for BCPAP and 0.37 for IHH4. CDX's other than 8505C showed low consistency, which agrees with studies comparing mRNA levels between human thyroid cancer cell lines and human thyroid tumors. Genomic profiles showed a correlation coefficient of only approximately 0.29 between thyroid cancer cell lines and human tumors, and this coefficient is the lowest among all types of cancer. Another study found a Spearman correlation coefficient $<0.3$ between ATC cell lines and primary tumors, and an even lower coefficient $<0.1$ between PTC lines and primary tumors [16]. 
Similarity between primary and xenograft tumors was further investigated at the level of individual cancer-related pathways. A total of 135 cancer-related pathways were identified based on KEGG analysis of gene enrichment in publications from MEDLINE. The similarity of each pathway was calculated based on the expression levels of all involved proteins more than differential proteins. The two PTC cell lines and three ATC cell lines in this study covered $54(40.0 \%)$ and $64(47.4 \%)$ of cancer-related pathways. Overall, these pathways showed moderate similarity between CDX's and human tumors. More than $70 \%$ of pathways showed low consistency between the two tumor types. Even in the cell line showing the highest consistency, 8505C, only $33.33 \%$ of pathways showed high consistency with primary tumors. Up to one quarter of pathways $(11.9-24.4 \%)$ showed correlation coefficients $<0.25$. Priority recommended cell lines were identified for approximately 40 percent of 135 pathways (53 in PTC and 64 in ATC). BCPAP was identified as being not recommended for 15 (11.11\%) of pathways with $\mathrm{r}<$ 0.25; IHH4, 26 (19.26\%) pathways; 8305C, 14 (10.37\%) pathways; $8505 \mathrm{C}$ for 32 (23.70\%) pathways; and FRO, $33(24.44 \%)$ pathways.
The heterogeneous consistency between primary and xenograft tumors at the level of individual pathways suggests that no single CDX model fits most pathways important in thyroid cancer. Our finding that many immunology-related pathways, such as those involving Toll-like receptors, TNF, or NF-kB, show low consistency between primary and xenograft tumor types likely reflects the immunosuppression intrinsic to nude mice. The lack of consistency in the hedgehog pathway between primary and xenograft PTC or ATC tumors is an important reminder of the need to choose cancer cell lines cautiously. The hedgehog pathway is activated to stimulate the growth and spread of many types of solid tumors, including thyroid cancer. It may also affect patient prognosis, but this remains controversial [23, 24]. Inhibiting hedgehog signaling by knocking down key genes or applying small-molecule inhibitors significantly reduces cell proliferation [24]. In fact, two small-molecule inhibitors of hedgehog signaling, cyclopamine and GDC-0449, have been explored in vitro as candidates for thyroid cancer treatment $[25,26]$. Interestingly, the pathway "thyroid cancer" showed low similar between primary PTC tumors and IHH4 or BCPAP-derived xenografts.

Table 4. Cancer-related pathways grouped based on their similarity between primary and xenograft PTC tumors

\begin{tabular}{|c|c|c|c|c|c|}
\hline & \multicolumn{5}{|l|}{ Correlation coefficient } \\
\hline & $>0.6$ & & $0.25-0.6$ & $<0.25$ & \\
\hline BCPAP & $\begin{array}{l}\text { Sphingolipid, } \\
\text { Ubiquitin-mediated } \\
\text { proteolysis, Type II diabetes } \\
\text { mellitus, Prostate cancer, } \\
\text { Pertussis, Colorectal cancer, } \\
\text { Endometrial cancer, Notch, } \\
\text { Hippo, Leukocyte } \\
\text { transendothelial migration, } \\
\text { Bacterial invasion of } \\
\text { epithelial cells, Homologous } \\
\text { recombination, Adherens } \\
\text { junction, Chemokine, } \\
\text { Pathogenic Escherichia coli } \\
\text { infection }\end{array}$ & $\begin{array}{l}\text { Shigellosis, Regulation } \\
\text { of actin cytoskeleton, } \\
\text { Leishmaniasis, Viral } \\
\text { carcinogenesis, Acute } \\
\text { myeloid leukemia, } \\
\text { Choline metabolism in } \\
\text { cancer, Estrogen, } \\
\text { Hepatitis C, NOD-like } \\
\text { receptor, Measles, } \\
\text { AMPK, Type I diabetes } \\
\text { mellitus, Drug } \\
\text { metabolism - } \\
\text { cytochrome P450, } \\
\text { Dorso-ventral axis }\end{array}$ & $\begin{array}{l}\text { ErbB, HTLV-I infection, Glioma, } \\
\text { Neurotrophin, TNF, Bladder cancer, } \\
\text { Allograft rejection, Graft-versus-host disease, } \\
\text { Osteoclast differentiation, Focal adhesion, } \\
\text { Cell cycle, VEGF, Hepatitis B, Arachidonic } \\
\text { acid metabolism, Toxoplasmosis, cAMP, B } \\
\text { cell receptor, Chemical carcinogenesis, } \\
\text { Non-small cell lung cancer, Herpes simplex } \\
\text { infection, Proteoglycans in cancer, Gap } \\
\text { junction, Influenza A, Epithelial cell } \\
\text { signaling, Helicobacter pylori infection, } \\
\text { Antigen processing and presentation, Fc } \\
\text { gamma R-mediated phagocytosis, Ras, Viral } \\
\text { myocarditis, Renal cell carcinoma, GnRH, }\end{array}$ & $\begin{array}{l}\text { Mismatch repair, Base } \\
\text { excision repair, Nucleotide } \\
\text { excision repair, p53, Steroid } \\
\text { hormone biosynthesis, } \\
\text { Non-homologous end-joining, } \\
\text { Ovarian steroidogenesis }\end{array}$ & $\begin{array}{l}\text { Hedgehog, } \\
\text { Thyroid cancer, } \\
\text { Basal cell } \\
\text { carcinoma, } \\
\text { Linoleic acid } \\
\text { metabolism, } \\
\text { Caffeine } \\
\text { metabolism, } \\
\text { Hematopoietic } \\
\text { cell lineage, } \\
\text { African } \\
\text { trypanosomiasis, } \\
\text { Adipocytokine, } \\
\text { RIG-I-like }\end{array}$ \\
\hline IHH4 & $\begin{array}{l}\text { Steroid hormone } \\
\text { biosynthesis, } \\
\text { Non-homologous } \\
\text { end-joining, Ovarian } \\
\text { steroidogenesis, TGF-beta, } \\
\text { Aldosterone-regulated } \\
\text { sodium reabsorption, } \\
\text { Cytokine-cytokine receptor } \\
\text { interaction, Malaria, } \\
\text { Progesterone-mediated } \\
\text { oocyte maturation, mTOR, } \\
\text { Amyotrophic lateral sclerosis, } \\
\text { Cell adhesion molecules, } \\
\text { Thyroid hormone synthesis, } \\
\text { Endocytosis, Oocyte meiosis, } \\
\text { HIF-1, Chagas disease, Rap1, } \\
\text { Regulation of lipolysis in } \\
\text { adipocytes, Autoimmune } \\
\text { thyroid disease }\end{array}$ & $\begin{array}{l}\text { formation, Pancreatic } \\
\text { cancer, Legionellosis, } \\
\text { Salmonella infection, } \\
\text { Central carbon } \\
\text { metabolism in cancer, } \\
\text { Jak-STAT, Apoptosis }\end{array}$ & $\begin{array}{l}\text { Rheumatoid arthritis, Wnt, Pathways in } \\
\text { cancer, Toll-like receptor, Melanoma, Insulin, } \\
\text { PI3K-Akt, Non-alcoholic fatty liver disease, } \\
\text { Epstein-Barr virus infection, Natural killer } \\
\text { cell-mediated cytotoxicity, Tuberculosis, T } \\
\text { cell receptor, Fc epsilon RI, MAPK, Chronic } \\
\text { myeloid leukemia, Long-term depression, } \\
\text { Prolactin, Metabolism of xenobiotics by } \\
\text { cytochrome P450, Transcriptional } \\
\text { misregulation in cancer, FoxO, Axon } \\
\text { guidance, TGF-beta, Aldosterone-regulated } \\
\text { sodium reabsorption, Cytokine-cytokine } \\
\text { receptor interaction, Malaria, } \\
\text { Progesterone-mediated oocyte maturation, } \\
\text { mTOR, Amyotrophic lateral sclerosis, Cell } \\
\text { adhesion molecules, Thyroid hormone } \\
\text { synthesis, Endocytosis, Oocyte meiosis, } \\
\text { HIF-1-, Chagas disease, Rap1, Regulation of } \\
\text { lipolysis in adipocytes, Autoimmune thyroid } \\
\text { disease }\end{array}$ & $\begin{array}{l}\text { Glutathione metabolism, } \\
\text { Long-term potentiation, } \\
\text { Inflammatory mediator } \\
\text { regulation of TRP, channels, } \\
\text { Small cell lung cancer, } \\
\text { Thyroid hormone, } \\
\text { MicroRNAs in cancer, } \\
\text { Signaling pathways } \\
\text { regulating pluripotency of } \\
\text { stem cells, Intestinal immune } \\
\text { network for IgA production, } \\
\text { Amoebiasis, Complement and } \\
\text { coagulation cascades, Fanconi } \\
\text { anemia pathway, } \\
\text { Inflammatory bowel disease, } \\
\text { NF-kappa B, Insulin } \\
\text { resistance, Prion diseases, } \\
\text { Drug metabolism - other } \\
\text { enzymes }\end{array}$ & $\begin{array}{l}\text { receptor, } \\
\text { Melanogenesis }\end{array}$ \\
\hline
\end{tabular}


Table 5. PTC-related pathways recommended for cell line-based studies based on consistency with CDX's

\begin{tabular}{|c|c|c|c|c|}
\hline \multirow[t]{2}{*}{ Cell line } & \multicolumn{3}{|l|}{ Top 1 consistency } & \multirow[t]{2}{*}{ Non-top 1} \\
\hline & Low consistency & Moderate consistency & High consistency & \\
\hline ВСРАР & $\begin{array}{l}\text { Thyroid cancer, } \\
\text { Basal cell } \\
\text { carcinoma, } \\
\text { Caffeine } \\
\text { metabolism, } \\
\text { Linoleic acid } \\
\text { metabolism, } \\
\text { Hematopoietic } \\
\text { cell lineage, } \\
\text { RIG-I-like } \\
\text { receptor } \\
\text { signaling } \\
\text { pathway, } \\
\text { Melanogenesis }\end{array}$ & $\begin{array}{l}\text { Glutathione metabolism, Long-term potentiation, Inflammatory } \\
\text { mediator regulation of TRP channels, Neurotrophin signaling } \\
\text { pathway, TNF signaling pathway, Small cell lung cancer, Thyroid } \\
\text { hormone signaling pathway, Bladder cancer, MicroRNAs in } \\
\text { cancer, Signaling pathways regulating pluripotency of stem cells, } \\
\text { Intestinal immune network for IgA production, Focal adhesion, } \\
\text { Amoebiasis, VEGF signaling pathway, Hepatitis B, Arachidonic } \\
\text { acid metabolism, Toxoplasmosis, Chemical carcinogenesis, } \\
\text { Non-small cell lung cancer, Complement and coagulation } \\
\text { cascades, Epithelial cell signaling in Helicobacter pylori infection, } \\
\text { Antigen processing and presentation, Fc gamma R-mediated } \\
\text { phagocytosis, Viral myocarditis, GnRH signaling pathway, } \\
\text { Fanconi anemia pathway, Wnt signaling pathway, Pathways in } \\
\text { cancer, Insulin signaling pathway, PI3K-Akt signaling pathway, } \\
\text { Inflammatory bowel disease, Non-alcoholic fatty liver disease, } \\
\text { NF-kappa B signaling pathway, Insulin resistance, Epstein-Barr } \\
\text { virus infection, Natural killer cell-mediated cytotoxicity, Prion } \\
\text { diseases, T cell receptor signaling pathway, Fc epsilon RI } \\
\text { signaling pathway, MAPK signaling pathway, Long-term } \\
\text { depression, Prolactin signaling pathway, Metabolism of } \\
\text { xenobiotics by cytochrome P450, Drug metabolism - other } \\
\text { enzymes, Transcriptional misregulation in cancer, FoxO } \\
\text { signaling pathway, Axon guidance }\end{array}$ & $\begin{array}{l}\text { Sphingolipid signaling pathway, } \\
\text { Ubiquitin-mediated proteolysis, Type II } \\
\text { diabetes mellitus, Prostate cancer, Pertussis, } \\
\text { Colorectal cancer, Viral carcinogenesis, } \\
\text { Acute myeloid leukemia, Endometrial } \\
\text { cancer, Notch signaling pathway, Hippo } \\
\text { signaling pathway, Hepatitis C, Leukocyte } \\
\text { transendothelial migration, Bacterial } \\
\text { invasion of epithelial cells, Homologous } \\
\text { recombination, AMPK signaling pathway, } \\
\text { Adherens junction, Type I diabetes mellitus, } \\
\text { Chemokine signaling pathway, Drug } \\
\text { metabolism - cytochrome P450, Pancreatic } \\
\text { cancer, Legionellosis, Central carbon } \\
\text { metabolism in cancer, Pathogenic Escherichia } \\
\text { coli infection, Jak-STAT signaling pathway, } \\
\text { Apoptosis }\end{array}$ & $\begin{array}{l}\text { Shigellosis, } \\
\text { Regulation of actin } \\
\text { cytoskeleton, } \\
\text { Leishmaniasis, } \\
\text { Choline } \\
\text { metabolism in } \\
\text { cancer, Estrogen } \\
\text { signaling pathway, } \\
\text { NOD-like receptor } \\
\text { signaling pathway, } \\
\text { Measles, } \\
\text { Dorso-ventral axis } \\
\text { formation, } \\
\text { Salmonella infection }\end{array}$ \\
\hline IHH4 & $\begin{array}{l}\text { Hedgehog } \\
\text { signaling } \\
\text { pathway, } \\
\text { Caffeine } \\
\text { metabolism, } \\
\text { Linoleic acid } \\
\text { metabolism, } \\
\text { African } \\
\text { trypanosomiasis, } \\
\text { Adipocytokine } \\
\text { signaling } \\
\text { pathway }\end{array}$ & $\begin{array}{l}\text { Mismatch repair, Base excision repair, Nucleotide excision repair, } \\
\text { p53 signaling pathway, Non-homologous end joining, ErbB } \\
\text { signaling pathway, HTLV-I infection, Glioma, Allograft rejection, } \\
\text { Graft-versus-host disease, Osteoclast differentiation, Cell cycle, } \\
\text { cAMP signaling pathway, B cell receptor signaling pathway, } \\
\text { Herpes simplex infection, Proteoglycans in cancer, Gap junction, } \\
\text { Influenza A, Ras signaling pathway, Renal cell carcinoma, } \\
\text { Rheumatoid arthritis, Toll-like receptor signaling pathway, } \\
\text { Melanoma, Tuberculosis, Chronic myeloid leukemia }\end{array}$ & $\begin{array}{l}\text { Steroid hormone biosynthesis, Ovarian } \\
\text { steroidogenesis, TGF-beta signaling } \\
\text { pathway, Aldosterone-regulated sodium } \\
\text { reabsorption, Cytokine-cytokine receptor } \\
\text { interaction, Malaria, Progesterone-mediated } \\
\text { oocyte maturation, mTOR signaling } \\
\text { pathway, Amyotrophic lateral sclerosis, Cell } \\
\text { adhesion molecules, Thyroid hormone } \\
\text { synthesis, Endocytosis, Oocyte meiosis, } \\
\text { HIF-1 signaling pathway, Chagas disease, } \\
\text { Rap1 signaling pathway, Regulation of } \\
\text { lipolysis in adipocytes, Autoimmune } \\
\text { thyroid disease, Shigellosis, Regulation of } \\
\text { actin cytoskeleton, Leishmaniasis, Choline } \\
\text { metabolism in cancer, Estrogen signaling } \\
\text { pathway, NOD-like receptor signaling } \\
\text { pathway, Measles, Dorso-ventral axis } \\
\text { formation, Salmonella infection }\end{array}$ & $\begin{array}{l}\text { Viral } \\
\text { carcinogenesis, } \\
\text { Acute myeloid } \\
\text { leukemia, Hepatitis } \\
\text { C, AMPK signaling } \\
\text { pathway, Drug } \\
\text { metabolism - } \\
\text { cytochrome P450, } \\
\text { Pancreatic cancer, } \\
\text { Legionellosis, } \\
\text { Central carbon } \\
\text { metabolism in } \\
\text { cancer, Jak-STAT } \\
\text { signaling pathway, } \\
\text { Apoptosis }\end{array}$ \\
\hline
\end{tabular}

Although few drugs have been approved for treating thyroid cancer, we compared the profile of 672 FDA-approved druggable proteins between primary and xenograft thyroid tumors. These proteins target enzymes, transporters, voltage-gated ion channels, G-protein coupled receptors, nuclear receptors and $\mathrm{CD}$ markers. A total of 93 druggable proteins were detected in primary PTC tumors, and only $44 \%$ of druggable proteins were expressed in both PTC cell lines. More than $30 \%$ of proteins were not detected in either of these lines. A total of 76 druggable proteins were detected in primary ATC tumors, of which 31 were detected in all three ATC cell lines, 22 were detected in at least one line, and 13 were detected in two lines. On the other hand, 10 proteins (ABAT, ALOX5, AOC3, EPHA2, F9, FLT4, ITGAL, RAF1, SLCO2B1, TSPO) were not detected in any of the three lines. The differential expression-level of targeted proteins might partly indicated different response to approved drugs among xenograft models and primary tumors.

The proteomic consistency between human thyroid cancer tissue and xenografts derived from human thyroid cancer cell lines was investigated based on total protein, cancer-related proteins, and druggable proteins. The results indicate rather low consistency between primary and xenograft tumors. Most CDX's showed poor correlation with primary tumors $(\mathrm{r}<0.4)$, while the 8505C-derived xenograft showed medium correlation (0.545). At the level of individual cancer-related pathways, fewer than one third of pathways were highly similar between primary and xenograft tumors $(>0.60) ; 12.6-31.1 \%$ of pathways showed low similarity $(<0.25)$. Differences in druggable proteins were also observed between primary and xenograft tumors, as well as among xenograft tumors. 


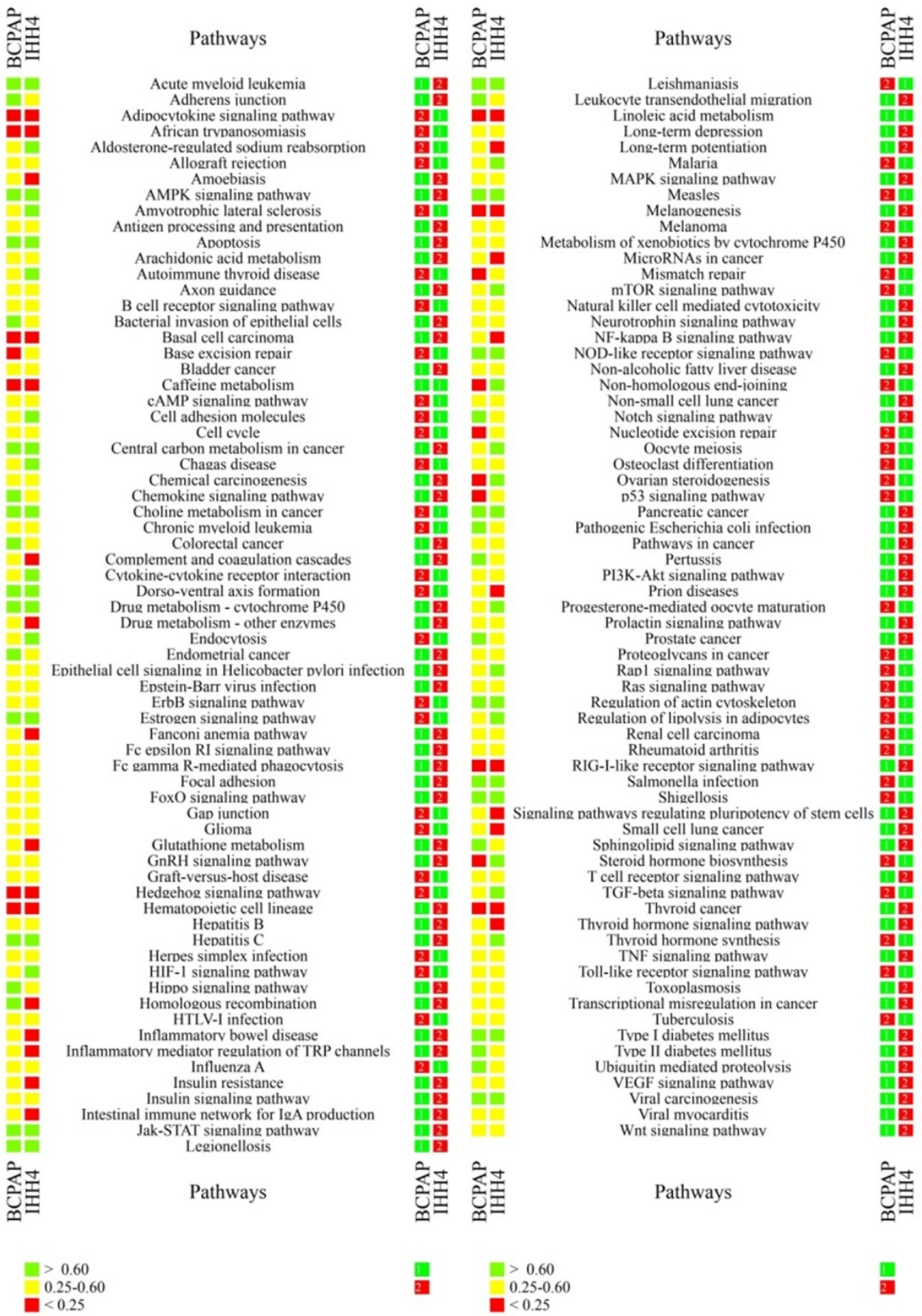

Figure 3. Ranking of individual cancer-related pathways based on correlation coefficients between primary and xenograft PTC tumors. The colored cubes on the left indicate the correlation coefficient as $>0.60$ (green), $0.25-0.60$ (gray), or $<0.25$ (red). The colored cubes on the right indicate the consistency as high (green) or low (red).

Key genes related to thyroid carcinoma, such as RET, p53, RAS, BRAF and $\beta$-catenin, should be additionally addressed. Therefore, the responding signaling pathway, included p53 signaling pathway, RAS signaling pathway, MAPK signaling pathways,
WNT signaling pathway, and PI3K-AKT/RAS signaling pathway were additionally discussed. Most signaling pathways were with moderate correlation $(\mathrm{r}=0.40-0.53)$ between xenografts and patients, except poor consistancy of p53 in PTC ( $r=0.23)$. 

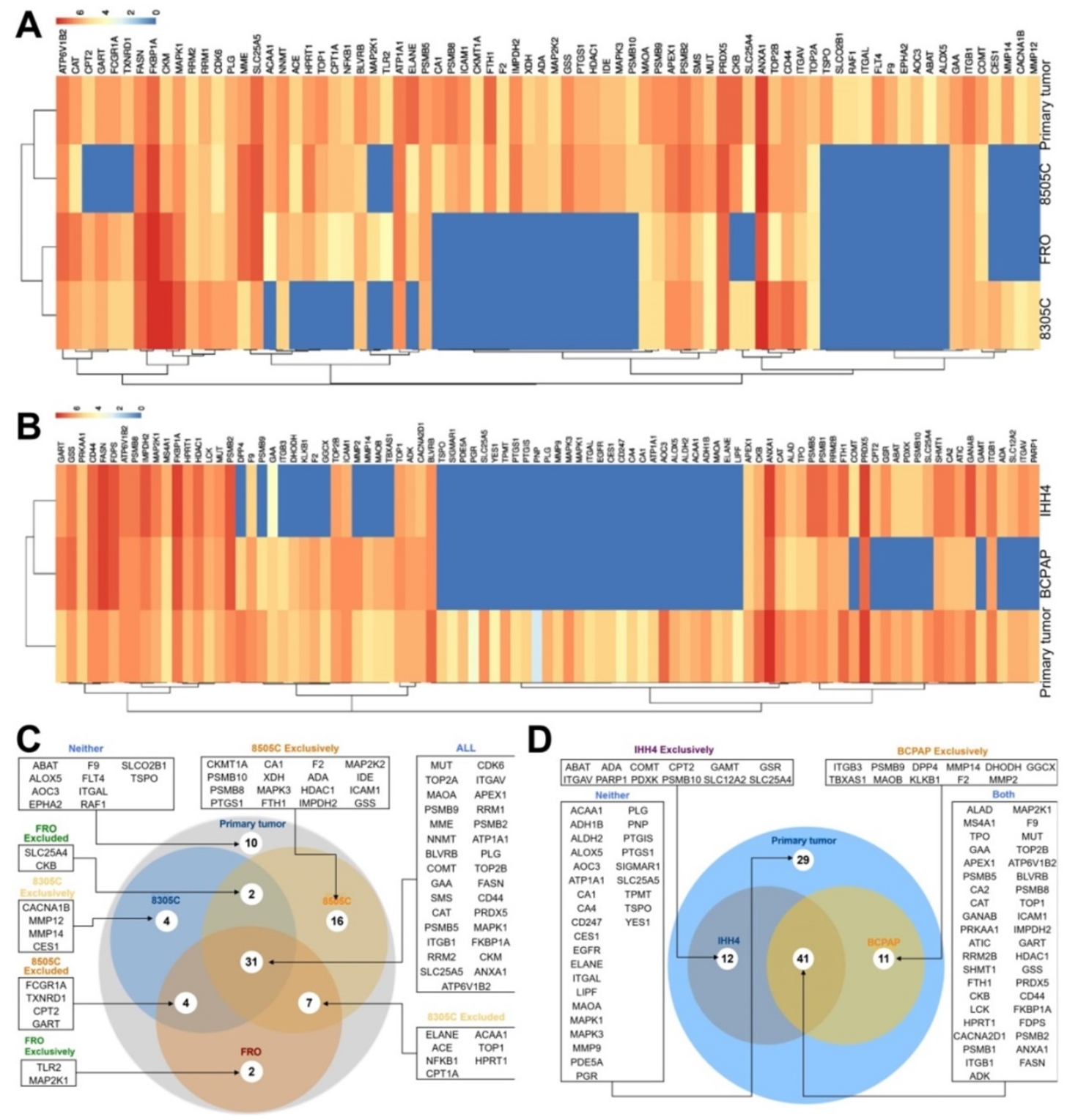

Figure 4. Expression of druggable proteins in primary and xenograft tumors of thyroid cancer. A-B, Heatmap of druggable protein levels detected in patient tumors and CDXs of (A) ATC and (B) PTC. C-D, Venn diagram showing overlap of druggable proteins detected in CDXs of (C) ATC and (D) PTC.

There're also limitations of subcutaneous xenograft tumor model. For example, subcutaneous tumor size variability was generally very low, and the proliferation rate was slower than orthotopic tumor model. These differences in overall growth indicated the crucial role of an appropriate microenvironment and organ-specific angiogenesis in facilitating initial tumor growth and perhaps later aggressiveness. Another important reason is that subcutaneous xenograft tumor model do not clearly reproduce the primary site of cancers and nor do they represent the common sites of metastasis. On the contrary, orthotopic tumor placement appears to better mimic the microenvironment, morphology, growth, and metastatic patterns of human cancer. Therefore, these limitations may also be important reasons for the poor correlation between the CDX model and the primary model in thyroid tumor in our study. Moreover, the mutation status, express levels of key genes should be focus in future studies.

\section{Abbreviations}

ATC: anaplastic thyroid carcinoma; PTC: papillary thyroid carcinoma; CDX: cell line-derived xenograft; FDR: false detection rate.

\section{Supplementary Material}

Supplementary figures and tables.

http://www.jcancer.org/v12p1978s1.zip

\section{Acknowledgement}

The authors thank Dr. Qin-jie Wen and Dr. Xiao-yang Dai at the Zhejiang Province Key 
Laboratory of Anti-Cancer Drug Research, College of Pharmaceutical Sciences, Zhejiang University, China, for creating the xenograft models. They also thank Dr. Qi-kang Gao at the Center of Analysis and Measurement, Zhejiang University, China, for HPLC and tandem mass spectrometry.

\section{Statement of Ethics}

This study was approved by the Ethics Committee of Zhejiang Cancer Hospital and performed according to the Declaration of Helsinki and Good Clinical Practice guidelines. Patients provided written informed consent for their tissue to be used in this study.

Animal studies were conducted according to the National Research Council's guidelines and approved by the Committee on the Ethics of Animal Experiments of Zhejiang Cancer Hospital and the Center for Drug Safety Evaluation at Zhejiang University.

\section{Funding Sources}

This study was supported by the Key Research and Development Program of Zhejiang Province (2021C0308), the National Natural Science Foundation of China (81672642, 81602349, 81773819, 81702644, 81802673,81872170 and 81973396), National Natural Science Foundation of China-Zhejiang Joint Fund under Grant (U20A20382), the Research Fund of the Ministry of Health Science(WKJ-ZJ-1605), the Medical and Health Research Program of Zhejiang Province (2015DTA003, 2016KYB045, 2018KY297, 2019KY047, 2019KY559), Chinese Medicine Research Program of Zhejiang Province (2018ZZ006, 2020ZZ003, 2021ZZ001), Zhejiang Provincial Natural Science Foundation of China, Zhejiang Province, People's Republic of China (LY20H310001, LYQ20H310001, LQ17H310002, Q17H300007), the "10000 Talents Plan" of Zhejiang Province (to Minghua $\mathrm{Ge}$ and Ping Huang), the Zhejiang Provincial Program for Leading Talents of Health (to Minghua Ge), the Zhejiang Provincial Program for the Cultivation of 151 Talents (to Ping Huang and Luo Fang), Zhejiang Provincial Program for the Cultivation of New Heath Talents (to Yiwen Zhang) and the Zhejiang Provincial Program for the Cultivation of High-level Innovative Heath Talents (to Ping Huang).

\section{Competing Interests}

The authors have declared that no competing interest exists.

\section{References}

1. Wilding JL, Bodmer WF. Cancer cell lines for drug discovery and development. Cancer Res. 2014; 74: 2377-84.
2. van Staveren WC, Solis DY, Hebrant A, Detours V, Dumont JE, Maenhaut C. Human cancer cell lines: Experimental models for cancer cells in situ? For cancer stem cells? Biochim Biophys Acta. 2009; 1795: 92-103.

3. Sasai K, Romer JT, Lee Y, Finkelstein D, Fuller C, McKinnon PJ, et al. Shh pathway activity is down-regulated in cultured medulloblastoma cells: implications for preclinical studies. Cancer Res. 2006; 66: 4215-22.

4. Harlin H, Gajewski TF. Diagnosis and treatment of mycoplasma-contaminated cell cultures. Curr Protoc Cytom. 2008; Appendix 3: Appendix 3C.

5. Biau J, Chautard E, Court F, Pereira B, Verrelle P, Devun F, et al. Global Conservation of Protein Status between Cell Lines and Xenografts. Transl Oncol. 2016; 9: 313-21.

6. Domcke S, Sinha R, Levine DA, Sander C, Schultz N. Evaluating cell lines as tumour models by comparison of genomic profiles. Nat Commun. 2013; $4: 2126$.

7. Sandberg R, Ernberg I. Assessment of tumor characteristic gene expression in cell lines using a tissue similarity index (TSI). Proc Natl Acad Sci U S A. 2005; 102: 2052-7.

8. Voskoglou-Nomikos T, Pater JL, Seymour L. Clinical predictive value of the in vitro cell line, human xenograft, and mouse allograft preclinical cancer models. Clin Cancer Res. 2003; 9: 4227-39.

9. Wang H, Huang S, Shou J, Su EW, Onyia JE, Liao B, et al. Comparative analysis and integrative classification of NCI60 cell lines and primary tumors using gene expression profiling data. BMC Genomics. 2006; 7: 166.

10. Zhao N, Liu YJ, Wei YZ, Yan ZC, Zhang Q, Wu C, et al. Optimization of cell lines as tumour models by integrating multi-omics data. Brief Bioinform. 2017; 18: 515-29.

11. Ertel A, Verghese A, Byers SW, Ochs M, Tozeren A. Pathway-specific differences between tumor cell lines and normal and tumor tissue cells. Mol Cancer. 2006; 5: 55

12. Barretina J, Caponigro G, Stransky N, Venkatesan K, Margolin AA, Kim S, et al. The Cancer Cell Line Encyclopedia enables predictive modelling of anticancer drug sensitivity. Nature. 2012; 483: 603-7.

13. Holliday DL, Speirs V. Choosing the right cell line for breast cancer research. Breast Cancer Res. 2011; 13: 215.

14. Ao L, Guo Y, Song XK, Guan QZ, Zheng WC, Zhang JH, et al. Evaluating hepatocellular carcinoma cell lines for tumour samples using within-sample relative expression orderings of genes. Liver Int. 2017; 37: 1688-96.

15. Tveit KM, Pihl A. Do cell lines in vitro reflect the properties of the tumours of origin? A study of lines derived from human melanoma xenografts. Br J Cancer. 1981; 44: 775-86.

16. Saiselet M, Floor S, Tarabichi M, Dom G, Hebrant A, van Staveren WC, et al. Thyroid cancer cell lines: an overview. Front Endocrinol (Lausanne). 2012; 3: 133.

17. Kim J, So S, Lee HJ, Park JC, Kim JJ, Lee H. DigSee: Disease gene search engine with evidence sentences (version cancer). Nucleic Acids Res. 2013; 41: W510-7.

18. Burkhardt AM, Zlotnik A. Translating translational research: mouse models of human disease. Cell Mol Immunol. 2013; 10: 373-4.

19. Holzapfel BM, Wagner F, Thibaudeau L, Levesque JP, Hutmacher DW. Concise review: humanized models of tumor immunology in the 21st century: convergence of cancer research and tissue engineering. Stem Cells. 2015; 33: 1696-704.

20. McMillin DW, Negri JM, Mitsiades CS. The role of tumour-stromal interactions in modifying drug response: challenges and opportunities. Nat Rev Drug Discov. 2013; 12: 217-28.

21. Morton JJ, Bird G, Refaeli Y, Jimeno A. Humanized Mouse Xenograft Models: Narrowing the Tumor-Microenvironment Gap. Cancer Res. 2016; 76: 6153-8.

22. Caponigro G, Sellers WR. Advances in the preclinical testing of cancer therapeutic hypotheses. Nat Rev Drug Discov. 2011; 10: 179-87.

23. Bian XH, Sun $\mathrm{H}$, Xue H, Zhang G, Zhang CH, Liu XL, et al. Expression and clinical significance of Shh/Gli-1 in papillary thyroid carcinoma. Tumour Biol. 2014; 35: 10523-8.

24. Xu X, Ding H, Rao G, Arora S, Saclarides CP, Esparaz J, et al. Activation of the Sonic Hedgehog pathway in thyroid neoplasms and its potential role in tumor cell proliferation. Endocr Relat Cancer. 2012; 19: 167-79.

25. Bohinc B, Michelotti G, Diehl AM. Hedgehog signaling in human medullary thyroid carcinoma: a novel signaling pathway. Thyroid. 2013; 23: 1119-26.

26. Hinterseher U, Wunderlich A, Roth S, Ramaswamy A, Bartsch DK, Hauptmann S, et al. Expression of hedgehog signalling pathway in anaplastic thyroid cancer. Endocrine. 2014; 45: 439-47. 